\title{
IS THE REDUCTION IN OLDER WORKERS' JOB TENURE A CAUSE FOR CONCERN?
}

\author{
Steven A. Sass and Anthony Webb
}

CRR WP 2010-20

Date Submitted: November 2010

Date Released: December 2010

\author{
Center for Retirement Research at Boston College \\ Hovey House \\ 140 Commonwealth Avenue \\ Chestnut Hill, MA 02467 \\ Tel: 617-552-1762 Fax: 617-552-0191 \\ http://crr.bc.edu
}

Steven A. Sass is program director at the Center for Financial Literacy at Boston College. Anthony Webb is a research economist at the Center for Retirement Research at Boston College. The research reported here was performed pursuant to a grant from the U.S. Social Security Administration (SSA) funded as part of the Retirement Research Consortium (RRC). The opinions and conclusion expressed are solely those of the authors and do not represent the opinions or policy of SSA, any agency of the federal government, the RRC, or Boston College.

(C) 2010, by Steven A. Sass and Anthony Webb. All rights reserved. Short sections of text, not to exceed two paragraphs, may be quoted without explicit permission provided that full credit, including $(\mathrm{C}$ notice, is given to the source. 


\title{
About the Center for Retirement Research
}

The Center for Retirement Research at Boston College, part of a consortium that includes parallel centers at the University of Michigan and the National Bureau of Economic Research, was established in 1998 through a grant from the Social Security Administration. The Center's mission is to produce first-class research and forge a strong link between the academic community and decision makers in the public and private sectors around an issue of critical importance to the nation's future. To achieve this mission, the Center sponsors a wide variety of research projects, transmits new findings to a broad audience, trains new scholars, and broadens access to valuable data sources.

\section{Center for Retirement Research at Boston College}

\author{
Hovey House \\ 140 Commonwealth Avenue \\ Chestnut Hill, MA 02467 \\ phone: 617-552-1762 fax: 617-552-0191 \\ e-mail: crr@bc.edu \\ crr.bc.edu
}

Affiliated Institutions:

The Brookings Institution

Massachusetts Institute of Technology

Syracuse University

Urban Institute 


\begin{abstract}
Using data from the Health and Retirement Study (HRS), we analyze trends in voluntary, pressured, and forced quits and risk factors associated with each type of quit. We show that leaving one's age-50 job between ages 50 and 56 in any of the above circumstances more than doubles the likelihood that an individual will be working part-time at age 60, relative to a base case of working full-time. Pressured and forced quits also substantially increase the likelihood that the individual will not be working for pay at that age. Statistical tests confirm that pressured quits represent a separate and distinct category with its own risk factors and that they cannot be regarded as a subset of either voluntary or forced quits.

We further show that job loss between ages 50 and 56, regardless of the circumstances, is associated with "messy" post-displacement employment histories that are not fully captured by analyses that focus solely on the first post-displacement job. The effects of job displacement are long-lasting. Displaced workers are more likely to job-hop, to suffer further involuntary job losses, and to experience subsequent unemployment than those who were still working for their age-50 employer at age 56.

Accumulating sufficient resources to provide an adequate income in retirement requires most individuals to work well into their 60s, preferably in well-paid, pensioned employment. Individuals who separate from their age-50 employer for whatever reason are at risk of missing out on their peak savings years and failing to prepare adequately for retirement.
\end{abstract}




\section{Introduction}

Job-changing among workers in their 50s has increased dramatically, with less than half of all men aged 58-62 employed full-time with their age-50 employer, compared to nearly three out of four men in the early 1980s (Munnell and Sass 2008). Job displacement - defined as job loss due to the elimination of the worker's job - shows no upward trend for workers this age (Munnell et al. 2006). These results suggest at first glance that voluntary job changes are the driving force behind the increased job mobility of older workers. Munnell and Sass (2008) hypothesize that any increase in voluntary quits could be the result of the decline in defined benefit pension coverage among older workers. The age- and tenure-related patterns of wealth accrual in defined benefit pension plans impose substantial costs on employees who choose to quit before their early retirement age, and the elimination of these constraints may increase job mobility and employee welfare. But the situation could be more nuanced, and some supposedly voluntary quits could in fact be pressured, for example in response to an actual or prospective cut in hours, or in anticipation of being laid off.

Using Health and Retirement Study (HRS) data, Chan and Stevens (1999, 2001, 2004) show that involuntary job loss at older ages is often followed by substantial periods of unemployment. Johnson and Kawachi (2007) show that displaced workers who eventually re-enter the labor force often do so at much reduced salaries. But the longerterm consequences of involuntary job loss are less clear. Workers may move on from their first post-separation job to jobs that provide pay and benefits closer to the levels enjoyed in the pre-separation job so that a comparison of pre-separation with first postseparation job may mislead.

If alternative jobs pay lower wages, either the income or substitution effect may dominate. Workers may either wholly or partially withdraw from the labor market, or extend their work lives to compensate for the reduction in earnings and periods of unemployment. Chan and Stevens (1999) found evidence that although involuntary job loss was associated with a reduction in participation rates in the short- and medium-term, workers suffering involuntary job loss planned to extend their work lives. But 
establishing whether workers choose, or are able to translate these plans into action, requires an extremely long panel dataset, extending from age 50 to age 60 , one that has only recently become available.

This paper addresses three issues. We first identify and explain trends in job transition, distinguishing between voluntary, pressured, and forced quits by workers in their 50s. We provide descriptive statistics, and then estimate econometric models that control for local labor market conditions and pension type. We find that pressured quits cannot be regarded as a subset of either voluntary or forced quits and are a separate and distinct category. We then investigate the impact of job loss at older ages on the age of final retirement. We show that job separation between ages 50 and 56, for whatever reason, is associated with substantial reductions in the probabilities of working full-time, or working at all, at age 60.

We then investigate the subsequent employment history of displaced workers in more detail. Previous research has focused on the first post-displacement job. We show that involuntary and pressured job loss between ages 50 and 56 is often followed by "messy" employment patterns, so that focusing solely on the first post-displacement job fails to capture the long-term consequences of involuntary job loss. Displaced workers appear to have difficulties re-establishing themselves in the labor market that extend beyond their first post-displacement job. They are more likely to job-hop, to suffer further involuntary job losses, and to experience subsequent unemployment than those who were still working for their age-50 employer at age 56. Financial preparation for retirement requires well-paid, preferably pensioned employment, uninterrupted by periods of unemployment. The disruption of these workers' employment histories may substantially increase the risk that they will be unable to maintain their pre-retirement standard of living in retirement.

The remainder of the paper is organized as follows. Section One discusses the background and reviews previous literature. Section Two describes the data. Section Three presents our methodology and results, and Section Four concludes. 


\section{Background and previous research}

Continued employment at older ages is critical to retirement income security. Periods of unemployment can deplete workers' retirement savings. Workers who prematurely withdraw from the labor market may also claim Social Security benefits early, reducing income throughout retirement and increasing the risk of their surviving spouse falling into poverty in advanced old age. Workers who retire early also have fewer years to accumulate financial wealth, and if they start drawing down that wealth at younger ages, must reduce their withdrawal rate to avoid outliving their assets.

Munnell and Sass (2008) report a substantial decline in job tenure among older workers. Using data from the Current Population Survey (CPS), they show that median job tenure among men aged 55-64 declined substantially between 1991 and 1996. Job changing at older, but pre-retirement ages imposes substantial costs on workers covered by defined benefit pension plans, and they attribute this decline in tenure to the decline in defined benefit pension coverage among older workers that occurred around this time. These declines in tenure are reflected in an increase in job mobility among older workers. In 2004, only 28 percent of men aged 58-62 were working for their age-50 employer, compared with 45 percent in 1983 (Munnell and Sass, 2008). Munnell, Sass, Soto, and Zhivan (2006) show that there has been no increase in involuntary job loss from 1984 to 2004. The stability in involuntary job loss suggests that much of the increase in job mobility has been voluntary.

If this hypothesis is correct, the increase in mobility may improve well-being, by enabling older workers to move to jobs that better suit them. But Munnell, Sass, Soto, and Zhivan (2006) show that it is tenure, rather than age or education, that protects workers against involuntary job loss, so that the price of moving to a preferred job may be a reduction in job security and an increased risk of subsequent involuntary job loss. An additional concern is that some seemingly voluntary quits may have been in circumstances where the employee was, in one way or another, pressured to leave. 
In a series of papers, Chan and Stevens investigate the subsequent employment outcomes of displaced workers. Chan and Stevens (1999) find that involuntary job loss is associated with extensive periods of unemployment, and substantial reductions in earnings. Their analysis likely understates the magnitude of these reductions in earnings because earnings are only observed for those who actually obtain re-employment. They find that displacement causes men to revise their work expectations toward later retirement. But during the years studied by Chan and Stevens people who were not currently employed were not asked to estimate the probabilities that they would be working, with the result that these responses suffer from selection bias. In 2006, for the first time, HRS participants were asked to estimate the probabilities that they would be working at ages 62 and 65 . Our analysis of the 2006 data shows that workers suffering voluntary and involuntary separations anticipate much lower labor supply at older ages than those who retain their age 50 job. Among individuals who did not experience a separation between ages 50 and 56, the above probabilities were 50 and 29 percent, respectively. Among those who voluntarily left their age-50 job by age 56, the corresponding averages were 36 and 21 percent, and among those who lost their age-50 job involuntarily, the corresponding averages were 39 and 21 percent. Workers suffering voluntary and involuntary separations anticipate much lower labor supply at older ages than those who retain their age-50 job.

Chan and Stevens (2001) show that the effect of involuntary job loss on labor force participation rates can be long-lasting. Four years after displacement, the employment rate of displaced workers is 20 percent lower than that of the non-displaced. They also find that displaced workers initially experience higher quit rates from their postdisplacement jobs, pointing to the need to focus not only on the first post-displacement job, but also on subsequent jobs.

Displacement changes the pension incentives faced by workers covered by defined benefit pension plans. Covered workers suffer a loss of pension wealth, and may face quite different pension incentives in their post-displacement job that may potentially 
affect their labor supply. But Chan and Stevens (2004) show that only a small part of the reduction in labor force participation reflects changes in pension incentives.

Johnson and Kawachi (2007) show that the consequences of job changes at older ages depended crucially on why workers changed jobs and how long they held their former jobs. Workers generally experienced substantial wage declines, and were less likely to receive pension or health benefits on their new job. Wage declines were greatest for workers who quit a job that had lasted 10 years or more, and for those who were laid off. But regardless of the duration of the previous job or the circumstances of termination, workers generally reported that their new job was more enjoyable than the old. But their analysis may also understate the impact of job-loss, because we do not observe the terms on which those who are no longer working for pay could have obtained employment.

Von Wachter (2007); Friedberg, Munnell, Soto, and Zhivan (2008); and Friedberg, Owyang, and Webb (2008) show that local economic conditions can have a significant effect on retirement transitions. Friedberg, Owyang, and Webb (2008) show that when the unemployment rate is high, workers are at greater risk of involuntary retirement, but the incidence of voluntary job-to-job transitions is reduced. But their analysis does not separately identify pressured transitions. A potential problem is that what might be a voluntary quit in a good labor market might become a pressured quit in a weak labor market in which the worker has fewer outside options.

\section{Data}

We make use of data from the 1992 to 2008 waves of the HRS, which is a nationally representative panel of older Americans. Individuals born between 1931 and 1941 were interviewed every two years, starting in 1992; the panel was augmented in 1998 and 2004 by those born $1942-47$ and $1948-53$, respectively. ${ }^{1}$

Participants are asked about reasons for job changes, and are allowed to offer multiple explanations. We classify a quit as forced if the individual states that he quit because the

\footnotetext{
${ }^{1}$ The HRS oversamples blacks and residents of Florida. We use HRS sample weights to adjust for this.
} 
business closed, he was laid off or let go, or left because of poor health or disability. Pressured quits include any non-forced quits in which a supervisor or co-worker encouraged departure; wages or hours were about to be reduced; the employee would have been laid off had he not quit; or there was a change in duties, job location, or health insurance coverage. All remaining quits are classified as voluntary.

The HRS has two additional advantages for our purposes. First, it contains geographic identifiers that enable us to control for local labor market conditions. Second, we can use the panel aspect of the dataset to explore the long-run effects of job loss in middle age. ${ }^{2}$

When studying wave-to-wave job transitions, we use the data in pooled cross section. There are a total of 12,540 participants who were employed at time $t$, and who remained in the sample at time $t+2$. These yielded 41,958 person-wave observations. We focused primarily on the transitions of age-eligible individuals still in career employment, so we discard those aged less than 50 or more than 59 at time t, leaving 23,385. Of these, we discard 332 because the reason for leaving their previous wave job was not identified. In our multivariate analyses, we control for the Metropolitan or Micropolitan Statistical Area (MSA, mSA) unemployment rate. This is unknown when the respondent lives outside a MSA or mSA, resulting in the loss of a further 2,298 person-year observations. Excluding respondents with missing or zero sample weight, we are left with a final sample of 18,760 observations.

To study the long-term effects of job loss in late middle age, we follow HRS participants from ages 50 to 60 . Our sample comprises the 1,877 individuals who either attained age 50 between 1992 and 1998, or who were aged 50 or 51 at baseline in 1992, and who were working for an employer at that time. We drop 512 individuals who did not participate in one or more of the five subsequent interviews, and one whose employment status was not

\footnotetext{
${ }^{2}$ We use self-reported pension type in this version of the paper. While Gustman and Steinmeier (1999) showed that individuals report this information with substantial error, Chan and Stevens (2008) found that retirement responded more to one's beliefs about one's pension type, but also that, as people approached retirement, the accuracy of their information improved; therefore, it is reasonable to consider both measures. In a subsequent version of this paper, we plan to control for pension and Social Security wealth accruals, constructed from employer pension records and Social Security earnings histories.
} 
observed the first wave after they turned 60 , leaving 1,365. We classify individuals according to whether their first job change between ages 50 and 56 was voluntary, pressured, or forced, or if they had no such changes. The circumstances surrounding the first job change were unknown for 22 individuals, another 32 individuals have zero sample weights, and one has an unknown age-60 employment status, leaving a final sample of 1,310 individuals.

\section{Methodology and results}

Trends in job transitions

Table 1 shows the percentages of men and women aged 58-62 who were still working for their age-50 employer in 1992, 1998, and 2004. There was a statistically significant 8.5 percentage point decline in men working for their age-50 employer between 1992 and 1998, the proportion remaining stable thereafter. This reduction is consistent with Bureau of Labor Statistics data showing a substantial decline in tenure between 1991 and 1996, but relative stability thereafter. ${ }^{3}$ The percent of women working for their age-50 employer declined less between 1992 and 2004, reflecting the opposing effects of increased female attachment to the labor force and increased job mobility.

The above analyses may obscure important changes over time in the distribution of job tenure. Figures $1 \mathrm{~A}$ and $1 \mathrm{~B}$ show the cumulative distribution of job tenure of males (Figure 1A) and females (Figure 1B) aged 50-59 in 1992 and 2004. Between 1992 and 2004, the percentage of males with long tenure declined substantially - the 50th percentile of the distribution declined from 12.8 to 10.6 years, and the 75th percentile from 25.0 to 22.8 years. The 25th percentile declined by a much smaller amount, from 3.9 to 3.4 years. In contrast, there were much smaller declines between the above dates in the entire distribution of female job tenure, reflecting the growth over this period in female attachment to the labor force. The 50th percentile of female job tenure declined from 8.8 to 7.7 years, and there was little change at the 25th and 75th percentiles.

\footnotetext{
${ }^{3}$ CPS Publications (1997).
} 
Table 2 analyzes job transitions between one interview and the next among individuals aged 50-59 who were employed in 1992, 1998, and 2004. Overall, about one quarter of men and women left their previous wave job by the following wave. There were only modest education-related differences in the percentages quitting their previous wave job. Employees without pension coverage were more likely to quit their previous wave job than those covered by a pension, but there were no significant differences between employees covered by defined benefit plans and those covered only by a defined contribution plan. Some of the sample will have attained age 60, a common defined benefit pension plan retirement age, by the following wave, so the defined benefit quit rate may reflect lower quit rates at younger ages and higher quit rates past age 60 . Employees who have five or more years' tenure had significantly lower quit rates than those who had shorter tenure.

Only about 10 to 15 percent of quits were pressured, the great majority being either voluntary or forced. The percentage of quits that were involuntary varied substantially between the three waves. ${ }^{4}$ Men without a pension were substantially more likely to experience a forced quit. Employees who had more education were less likely to suffer a forced separation. The relatively small number of pressured quits means that variations in their incidence need to be interpreted with caution. But pressured quits appeared to be more frequent among workers with short tenure and without pension coverage. There are few clearly discernable trends over time. But it is possible that longer-term trends may be obscured by short run variations in the unemployment rate.

To further analyze job transitions, we estimate the following multinomial logit model using the HRS data in pooled cross section.

$$
\operatorname{Pr}\left[y_{i k}=j \mid x_{i}\right]=\frac{\exp \left(x_{i}^{\prime} \beta_{j}\right)}{1+\sum_{j=1}^{K} \exp \left(x_{i}^{\prime} \beta_{j}\right)}
$$

\footnotetext{
${ }^{4}$ These variations cannot be wholly explained by variations in the percent of separations of unknown type.
} 
We estimate the model for men and women separately, and to exclude individuals who are transitioning into retirement, restrict our sample to those aged between 50 and 60 at time $t$. In addition to the usual socio-economic controls, we include the Metropolitan or Micropolitan Statistical Area unemployment rate. ${ }^{5}$

Table 3 reports the estimated effects of each covariate in the form of relative risk ratios (RRR). ${ }^{6}$ The RRR is a transformation of the estimated logit coefficient and captures the marginal effect of the covariate on the likelihood of a particular job transition occurring relative to the likelihood of the base outcome (staying in the job) occurring. If the RRR takes a value equal to one, then the right-hand-side variable does not alter the likelihood of that particular job transition occurring relative to staying in the job. If the RRR takes a value that is smaller than one, then the variable reduces the likelihood of the job transition occurring relative to staying in the job by the percentage of RRR-1, and if the RRR takes a value greater than one, it raises the likelihood relative to staying in the job. The standard errors are transformed as well to correspond to the relative risk ratios and can be compared with RRR-1 using the critical values for z-statistics; so, if, upon computing RRR-1 and dividing by the transformed standard error reported in the table, one obtains a value that is roughly two, then that RRR is statistically significant at roughly the 95 percent confidence level.

There are significant socio-economic differences in the probabilities of experiencing various types of transitions. Men with less than a high school education, in good health, with long tenure, who are union members, and who have any kind of pension coverage are significantly and substantially less likely to involuntarily transition to a new job. Many of the above characteristics are associated with lower probabilites of experiencing pressured or voluntary quits to a new job. Those with less than a high school education are more likely to involuntarily retire, whereas those in good health, with employer health

\footnotetext{
${ }^{5}$ We also estimated models that included the percentage change in gross state product (GSP) instead of the MSA level unemployment rate. We found that the coefficients on GSP were rarely significant, and therefore only report results for the MSA models.

${ }^{6}$ Our model excluded wave dummies. We found that the wave dummies significantly affected unemployment rate coefficients. We concluded that the wave dummies were identifying the effects of cyclical variations in the national unemployment rate so that we could not interpret them as capturing the effects of a more general time trend.
} 
insurance coverage, a defined benefit or a defined contribution pension are more likely to involuntarily retire. Long-tenured employees and those with a defined benefit or a defined contribution pension are less likely to be pressured into retirement or voluntarily retire, the exception being workers with more than 20 years tenure, who are more likely to voluntarily retire.

The local unemployment rate frequently has a statistically significant effect on employment transitions. A 1 percent increase in the local unemployment rate is associated with a 10.9 percent increase in the risk of experiencing a pressured transition to a new job, a 6.4 percent decrease in the risk of a voluntary transition to a new job (1.00 minus 0.934 equals 0.066 ), a 7.3 percent decrease in the risk of a pressured retirement, and a 6.2 percent increase in the risk of voluntarily retiring. It is noteworthy that the local unemployment rate has no significant effect on the incidence of involuntary job loss. The unemployment rate measures the stock of unemployed workers at a point in time, and the incidence of job loss by older workers may be more strongly related to the rate of flow of workers into unemployment. In future work, we plan to experiment with alternative indicators of local labor market conditions.

Many of the same variables also affect female job transitions. For each of the six transition types, there is no statistically significant difference between the effects of the local unemployment rate on male and female relative risk ratios. There are significant differences in the effects of some other covariates. For example, women who have less than a high school education are much more likely to experience an involuntary or pressured quit to a new job, and more likely to voluntarily retire.

We then use the Cramer-Ridder test (Cramer and Ridder, 1991) to investigate whether pressured transitions to a new job or non-participation in the labor market occur in similar circumstances to either voluntary or involuntary quits to either a new job or nonparticipation in the labor market, or whether each type of pressured quit is a separate and distinct category. This test is equivalent to testing for equality of the regressor coefficients across the transitions of interest. Table Four reports our results. We can, 
with the exception of women's voluntary and pressured transitions to not working, reject at the 5 percent, and usually at the 1 percent, level of significance the hypothesis that the paired categories are arbitrary subdivisions of a larger class.

The impact of job changes on the age of retirement

We now investigate the impact of voluntary, pressured, and involuntary job changes in late middle age on career length. Although we have 16 years of data, it is in many cases as yet unclear whether workers have finally retired. We therefore study the labor force participation at age 60 of workers who attained age 50 between 1992 and 1998 and who therefore attained age 60 between 2002 and 2008. Table 5 shows the percentages of men and women who were 1) working full-time for their age-50 employer, 2) working fulltime for another employer, 3) working part-time for their age-50 employer, 4) working part-time for another employer, or 5) not working at the interview following their 60th birthday, analyzed by whether they voluntarily or involuntarily separated from their age50 employer between ages 50 and 56, or maintained continuity of employment. For the purposes of this analysis, we include "pressured" with involuntary quits. We then subdivide the fifth category, those not working at the interview following their 60th birthday, into those who state that they are looking for work, those who state that they are not looking for work, but are disabled, and those who are neither disabled nor looking for work.

Of men who were working for the same employer at both ages 50 and 56, 73 percent were working full-time at age 60, 4 percent were working part-time, and 23 percent were not working for pay. Of men who experienced involuntary job loss, 53 percent were working full-time, 13 percent part-time, and 34 percent were not working for pay. Of men who voluntarily quit their age-50 employer, only 48 percent were working full-time, 14 percent were working part-time, and 38 percent were not working.

Labor force participation rates vary substantially by pension type. Men who have a defined benefit pension were much less likely to be working at age 60 than those with a defined contribution pension or without any pension coverage. But the impact of 
involuntary separation, calculated by comparing the labor force participation rate of those experiencing an involuntary separation with that of workers who were still working for their age-50 employer at age 56, also differed substantially by pension type. For men covered by a defined benefit pension plan, involuntary separation was associated with a reduction of 16 percentage points in the probability of working at age 60. For men without any pension, it was associated with a reduction in the probability of working at age 60 of 20 percentage points. But for workers covered by a defined contribution pension plan, the decrease in the probability of working at age 60 was only 6 percent. Only very small percentages of men reported themselves as unemployed or disabled.

The patterns among women are quite different. Involuntary job loss has a much greater effect on the labor supply of both married and single women. Married women who do not change jobs between ages 50 and 56 are 4 percentage points more likely than men to be out of the labor market at age 60 ( 27 vs. 23 percent). But married women experiencing an involuntary job loss are 18 percentage points more likely to be out of the labor market (52 vs. 34 percent). The corresponding figures for unmarried women are minus 2 percentage points (21 vs. 23 percent) and 19 percentage points (53 vs. 34 percent). Women are also much more likely to report being unable to work as a result of a disability.

The above analyses show that the long-term effects of involuntary job loss vary substantially by gender, and either with pension type, or with factors that are, in turn, correlated with pension type. In particular, we infer that, relative to men, women's labor supply has a greater elasticity to not only wages, but also to adverse labor market shocks.

To further investigate the impact of involuntary job loss on labor force participation at older ages, we estimate a multinomial logit model in which our dependent variable distinguishes between those working full-time, working part-time, or not working for pay at age 60 . Table 6 reports relative risk ratios, which have the same interpretation as previously. 
Experiencing a voluntary or forced quit between 50 and 56 is associated with significant and substantial increases in the relative risks of either working part-time, or not working for pay. Experiencing a pressured quit is also associated with substantial increases in the above probabilities, but the coefficients are imprecisely estimated, reflecting the small proportions of individuals experiencing quits of this type. Many other variables have the expected signs. Long-tenured workers, those covered by defined benefit pension plans, who are in poor health at age 60, who are union members, and who have less than a high school education are less likely to be working for pay at age 60. Men are more likely to be working for pay. Few of the socio-economic variables have a significant effect on the probability of working part-time at age 60 , possibly reflecting the relatively small number of part-time workers.

Table 7 shows the impact of quits on the probabilities of working full- or part-time at age 60, holding all other variables constant at their means. Only 23.9 percent of workers who remain with their age-50 employer until age 56 are not working for pay at age 60 , compared with 43.9, 31.4, and 49.6 percent of those who experience voluntary, pressured, or forced quits.

A potential concern with the above analysis is unobserved heterogeneity in worker tastes and abilities. Workers suffering involuntary or pressured job loss may be of unobservably lower quality, while those who voluntarily quit will often have a stronger taste for leisure. Lacking suitable instruments, we merely note the potential for bias in our estimates. $^{7}$

\section{Other indicia of longer-term employment outcomes}

Simply focusing on either the first post-layoff job or on employment status at age 60 may understate the long-term effects of job loss in late middle age. Workers experiencing involuntary job loss may drift from job to job, either experiencing further layoffs or quitting because the new job is not to their liking.

\footnotetext{
${ }^{7}$ We experimented unsuccessfully with using early out windows as an instrument for voluntary severance.
} 
We compare individuals who were still working for their age-50 employer at age 56 with those who left their age-50 job by age 56 as a result of a voluntary, pressured, or forced quit. We calculate a number of indicators of subsequent labor market outcomes. The first is the percent working at age 60, and discussed in the preceding paragraphs. The second is the total number of hours worked from age 50 to 60 . The third is the total number of full-time equivalent hours worked. The fourth, fifth, and sixth are the total number of jobs held between ages 50 and 60, the total number of periods of selfemployment, and the number of times the individual experienced involuntary job loss.

Those who are still in their age-50 job at age 56 work a total of 113 months between age 50 and 60. Those who experience voluntary, pressured, and forced quits work 84, 91, and 76 months, respectively. An almost identical pattern emerges in relation to full time equivalent months. Not surprisingly, those who change jobs between ages 50 and 56 have a larger total number of jobs between ages 50 and 60. We might expect them to have an average at most one more, or maybe somewhat less than one, because some people who quit their age-50 employer permanently leave the labor market. But the difference in the number of additional jobs is much larger $-1.59,2.31$, and 1.43 for those experiencing forced, pressured, and voluntary quits, respectively. Regardless of the circumstances surrounding the quit, quitters appear not to establish stable long-term employment relationships. This might reflect employee preferences, or correlations between employee types and the incidence of experiencing a quit in late middle age, but may also reflect the effects of the quit, and in particular, the loss of the protective effects of job tenure. The effects of job loss on the number of periods of self-employment and number of subsequent layoffs are much less pronounced. Excluding the layoff associated with the loss of the age-50 job, employees who retain their age-50 job have an average of 0.11 layoffs by age-60, whereas those experiencing voluntary, pressured, and forced quits experience averages of $0.13,0.35$, and 0.33 layoffs, respectively.

\section{Conclusions}

A categorization of quits between pressured and forced fails to recognize that many quits 
do not fall neatly into one of these two categories. There is likely a continuum of quit types ranging from the purely voluntary to those over which the employee had absolutely no control. A categorization of quits into voluntary and forced likely results in a substantial understatement of the proportion of workers who do not exit the labor force at a time and in a manner of their choosing.

Regardless of the circumstances of their departure, workers who do not stay with their age-50 employer are less likely to remain in the labor force at older ages. For those who voluntarily quit their age-50 employer, this must at least partially reflect a preference for early retirement. But this is unlikely to be the case for workers who experience forced or pressured quits. Those who do remain in the labor force are likely to experience "messy" subsequent work patterns, with further voluntary and involuntary severances, and multiple periods of unemployment, so that a focus on the first post-displacement job will not fully capture the long-term effects of job separation. 


\section{References}

Chan, Sewin, and Ann Huff Stevens. 1999. "Employment and Retirement Following a Late-Career Job Loss.” American Economic Review (89)2: 211-216.

Chan, Sewin, and Ann Huff Stevens. 2001. “Job Loss and Employment Patterns of Older Workers.” Journal of Labor Economics (19)2: 484-521.

Chan, Sewin, and Ann Huff Stevens. 2004. "How Does Job Loss Affect the Timing of Retirement?” Contributions to Economic Analysis and Policy (3)1

Chan, Sewin, and Ann Huff Stevens. 2008. “What You Don’t Know Can’t Help You: Pension Knowledge and Retirement Decision-Making.” Review of Economics and Statistics 90(2): 253-266.

CPS Publications. 1997. "Employee Tenure in the Mid-1990s" http://www.bls.census.gov/cps/pub/tenure_0296.htm

Cramer, Jan Salaomon, and Peter Den Ridder. 1991. "Pooling States in the Multinomial Logit Model." Journal of Econometrics (47) 267-272.

Friedberg, Leora, Michael Owyang, and Anthony Webb. 2008. "Identifying Local Differences in Retirement Patterns." Working Paper 2008-22. Chestnut Hill, MA: Center for Retirement Research at Boston College.

Gustman, Alan, and Thomas Steinmeier. 1999. "What People Don't Know About Their Pensions and Social Security: An Analysis Using Linked Data from the Health and Retirement Study.” Working Paper 7368. Cambridge, MA: National Bureau of Economic Research.

Johnson, Richard and Janette Kawachi. 2007. “Job Changes at Older Ages: Effects on Wages, Benefits, and Other Job Attributes.” Working Paper 2007-4. Chestnut Hill, MA: Center for Retirement Research at Boston College.

Munnell, Alicia H., Steven Sass, Mauricio Soto, and Natalia A. Zhivan. 2006. "Has the Displacement of Older Workers Increased?" Working Paper 2006-17. Chestnut Hill, MA: Center for Retirement Research at Boston College.

Munnell, Alicia H., and Steven Sass. 2008. Working Longer. Brookings Institution Press, Washington, DC. 
Von Wachter, Till. 2007. "The Effect of Economic Conditions on the Employment of Workers Nearing Retirement Age.” Working Paper 2007-25. Chestnut Hill, MA: Center for Retirement Research at Boston College. 
Figures and Tables

\begin{tabular}{|c|c|c|c|}
\hline Survey year & Males & Females & \\
\hline 1992 & 58.8 & 49.2 & \\
\hline 1998 & 50.3 & 48.7 & \\
\hline 2004 & 51.2 & 44.8 & \\
\hline
\end{tabular}




\begin{tabular}{|c|c|c|c|c|c|c|c|c|c|c|}
\hline & & \multirow{3}{*}{$\begin{array}{l}\text { With previous } \\
\text { wave employer }\end{array}$} & & & & & & & & \\
\hline & & & \multicolumn{4}{|c|}{ Working at subsequent interview } & \multicolumn{4}{|c|}{ Not working at next interview } \\
\hline & & & Voluntary & Pressured & Forced & Unknown & Voluntary & Pressured & Forced & Unknown \\
\hline \multicolumn{11}{|l|}{ Males } \\
\hline \multirow{3}{*}{ All } & 1992 & $76.8 \%$ & $4.6 \%$ & $1.6 \%$ & $5.6 \%$ & $0.0 \%$ & $4.5 \%$ & $1.0 \%$ & $5.9 \%$ & $0.0 \%$ \\
\hline & 1998 & $77.6 \%$ & $6.4 \%$ & $2.4 \%$ & $3.6 \%$ & $1.2 \%$ & $3.7 \%$ & $1.2 \%$ & $3.6 \%$ & $0.3 \%$ \\
\hline & 2004 & $78.9 \%$ & $5.5 \%$ & $1.8 \%$ & $4.5 \%$ & $1.2 \%$ & $2.8 \%$ & $0.7 \%$ & $4.3 \%$ & $0.3 \%$ \\
\hline \multirow{3}{*}{$\begin{array}{l}\text { Less than high school } \\
\text { education }\end{array}$} & 1992 & $76.2 \%$ & $3.9 \%$ & $1.3 \%$ & $7.1 \%$ & $0.0 \%$ & $2.9 \%$ & $1.3 \%$ & $7.2 \%$ & $0.0 \%$ \\
\hline & 1998 & $74.7 \%$ & $2.8 \%$ & $3.1 \%$ & $6.3 \%$ & $1.7 \%$ & $2.7 \%$ & $0.1 \%$ & $7.8 \%$ & $0.7 \%$ \\
\hline & 2004 & $78.8 \%$ & $1.8 \%$ & $0.4 \%$ & $8.4 \%$ & $0.0 \%$ & $2.6 \%$ & $0.0 \%$ & $7.5 \%$ & $0.5 \%$ \\
\hline \multirow[t]{3}{*}{ High School } & 1992 & $76.4 \%$ & $4.0 \%$ & $1.8 \%$ & $4.9 \%$ & $0.0 \%$ & $4.9 \%$ & $1.1 \%$ & $6.8 \%$ & $0.0 \%$ \\
\hline & 1998 & $78.0 \%$ & $5.5 \%$ & $1.6 \%$ & $4.1 \%$ & $1.8 \%$ & $3.0 \%$ & $1.9 \%$ & $3.5 \%$ & $0.7 \%$ \\
\hline & 2004 & $78.8 \%$ & $4.2 \%$ & $1.5 \%$ & $5.0 \%$ & $1.0 \%$ & $3.0 \%$ & $0.4 \%$ & $5.7 \%$ & $0.4 \%$ \\
\hline \multirow[t]{3}{*}{ Some college } & 1992 & $77.4 \%$ & $5.4 \%$ & $1.5 \%$ & $5.4 \%$ & $0.0 \%$ & $4.8 \%$ & $0.8 \%$ & $4.6 \%$ & $0.0 \%$ \\
\hline & 1998 & $78.3 \%$ & $7.9 \%$ & $2.6 \%$ & $2.6 \%$ & $0.8 \%$ & $4.4 \%$ & $1.0 \%$ & $2.5 \%$ & $0.0 \%$ \\
\hline & 2004 & $78.9 \%$ & $6.5 \%$ & $2.1 \%$ & $3.8 \%$ & $1.4 \%$ & $2.9 \%$ & $1.0 \%$ & $3.3 \%$ & $0.2 \%$ \\
\hline & & & & & & & & & & \\
\hline \multirow{3}{*}{$\begin{array}{l}\text { Less than five years } \\
\text { tenure }\end{array}$} & 1992 & $63.4 \%$ & $9.1 \%$ & $4.0 \%$ & $11.2 \%$ & $0.0 \%$ & $3.5 \%$ & $0.3 \%$ & $8.5 \%$ & $0.0 \%$ \\
\hline & 1998 & $60.5 \%$ & $12.8 \%$ & $4.3 \%$ & $7.9 \%$ & $2.8 \%$ & $3.7 \%$ & $1.5 \%$ & $6.0 \%$ & $0.6 \%$ \\
\hline & 2004 & $64.2 \%$ & $11.2 \%$ & $4.0 \%$ & $9.3 \%$ & $2.2 \%$ & $2.2 \%$ & $0.3 \%$ & $5.8 \%$ & $0.7 \%$ \\
\hline & 1992 & $82.2 \%$ & $2.8 \%$ & $0.6 \%$ & $3.4 \%$ & $0.0 \%$ & $4.9 \%$ & $1.3 \%$ & $4.8 \%$ & $0.0 \%$ \\
\hline Five or more years & 1998 & $85.3 \%$ & $3.5 \%$ & $1.5 \%$ & $1.7 \%$ & $0.5 \%$ & $3.7 \%$ & $1.0 \%$ & $2.5 \%$ & $0.2 \%$ \\
\hline tenure & 2004 & $85.6 \%$ & $2.9 \%$ & $0.7 \%$ & $2.3 \%$ & $0.8 \%$ & $3.1 \%$ & $0.9 \%$ & $3.6 \%$ & $0.1 \%$ \\
\hline & & & & & & & & & & \\
\hline No pension & 1992 & $61.9 \%$ & $9.5 \%$ & $3.4 \%$ & $10.7 \%$ & $0.0 \%$ & $3.7 \%$ & $1.2 \%$ & $9.7 \%$ & $0.0 \%$ \\
\hline & 1998 & $60.9 \%$ & $11.1 \%$ & $3.7 \%$ & $8.3 \%$ & $2.3 \%$ & $3.8 \%$ & $0.8 \%$ & $7.8 \%$ & $1.2 \%$ \\
\hline & 2004 & $67.2 \%$ & $8.5 \%$ & $3.0 \%$ & $8.2 \%$ & $1.8 \%$ & $2.6 \%$ & $0.5 \%$ & $7.3 \%$ & $1.0 \%$ \\
\hline DC pension only & 1992 & $82.9 \%$ & $2.3 \%$ & $1.2 \%$ & $7.2 \%$ & $0.0 \%$ & $1.6 \%$ & $0.6 \%$ & $4.0 \%$ & $0.0 \%$ \\
\hline & 1998 & $80.3 \%$ & $8.1 \%$ & $2.2 \%$ & $3.1 \%$ & $0.8 \%$ & $1.9 \%$ & $0.8 \%$ & $2.8 \%$ & $0.0 \%$ \\
\hline & 2004 & $81.3 \%$ & $4.1 \%$ & $2.3 \%$ & $4.9 \%$ & $1.9 \%$ & $3.1 \%$ & $0.2 \%$ & $2.2 \%$ & $0.0 \%$ \\
\hline & & & & & & & & & & \\
\hline DB pension & 1992 & $82.5 \%$ & $2.9 \%$ & $0.7 \%$ & $2.2 \%$ & $0.0 \%$ & $6.1 \%$ & $1.0 \%$ & $4.6 \%$ & $0.0 \%$ \\
\hline & 1998 & $85.6 \%$ & $2.9 \%$ & $1.7 \%$ & $1.2 \%$ & $0.8 \%$ & $4.7 \%$ & $1.5 \%$ & $1.6 \%$ & $0.0 \%$ \\
\hline & 2004 & $85.4 \%$ & $4.4 \%$ & $0.4 \%$ & $1.6 \%$ & $0.3 \%$ & $2.9 \%$ & $1.3 \%$ & $3.8 \%$ & $0.0 \%$ \\
\hline & & & & & & & & & & \\
\hline Females & & & & & & & & & & \\
\hline & & & & & & & & & & \\
\hline All & 1992 & $75.6 \%$ & $4.1 \%$ & $2.3 \%$ & $4.5 \%$ & $0.0 \%$ & $6.0 \%$ & $1.3 \%$ & $6.2 \%$ & $0.0 \%$ \\
\hline & 1998 & $73.9 \%$ & $7.3 \%$ & $1.8 \%$ & $4.4 \%$ & $1.3 \%$ & $4.2 \%$ & $1.3 \%$ & $5.2 \%$ & $0.5 \%$ \\
\hline & 2004 & $74.3 \%$ & $6.9 \%$ & $3.0 \%$ & $2.7 \%$ & $1.4 \%$ & $4.4 \%$ & $0.8 \%$ & $6.2 \%$ & $0.4 \%$ \\
\hline & & & & & & & & & & \\
\hline & 1992 & $71.8 \%$ & $4.9 \%$ & $1.8 \%$ & $5.0 \%$ & $0.0 \%$ & $5.2 \%$ & $1.6 \%$ & $9.8 \%$ & $0.0 \%$ \\
\hline Less than high school & 1998 & $70.0 \%$ & $5.4 \%$ & $0.0 \%$ & $4.8 \%$ & $0.6 \%$ & $5.5 \%$ & $0.3 \%$ & $11.3 \%$ & $2.1 \%$ \\
\hline education & 2004 & $68.5 \%$ & $5.3 \%$ & $2.8 \%$ & $1.5 \%$ & $0.8 \%$ & $5.4 \%$ & $0.9 \%$ & $14.4 \%$ & $0.2 \%$ \\
\hline High School & 1992 & $73.5 \%$ & $3.9 \%$ & $3.3 \%$ & $5.2 \%$ & $0.0 \%$ & $6.5 \%$ & $1.4 \%$ & $6.2 \%$ & $0.0 \%$ \\
\hline & 1998 & $76.0 \%$ & $5.6 \%$ & $1.0 \%$ & $5.2 \%$ & $1.8 \%$ & $3.6 \%$ & $1.5 \%$ & $5.4 \%$ & $0.0 \%$ \\
\hline & 2004 & $75.2 \%$ & $5.3 \%$ & $2.5 \%$ & $2.4 \%$ & $1.9 \%$ & $3.8 \%$ & $0.4 \%$ & $7.9 \%$ & $0.6 \%$ \\
\hline & & & & & & & & & & \\
\hline Some college & 1992 & $79.4 \%$ & $4.0 \%$ & $1.4 \%$ & $3.6 \%$ & $0.0 \%$ & $5.9 \%$ & $1.1 \%$ & $4.5 \%$ & $0.0 \%$ \\
\hline & 1998 & $73.1 \%$ & $9.1 \%$ & $2.8 \%$ & $3.8 \%$ & $1.2 \%$ & $4.4 \%$ & $1.4 \%$ & $3.7 \%$ & $0.5 \%$ \\
\hline & 2004 & $74.4 \%$ & $8.0 \%$ & $3.3 \%$ & $2.9 \%$ & $1.1 \%$ & $4.6 \%$ & $0.9 \%$ & $4.4 \%$ & $0.3 \%$ \\
\hline & & & & & & & & & & \\
\hline & 1992 & $64.9 \%$ & $6.9 \%$ & $3.9 \%$ & $7.7 \%$ & $0.0 \%$ & $6.4 \%$ & $1.5 \%$ & $8.8 \%$ & $0.0 \%$ \\
\hline Less than five years & 1998 & $58.7 \%$ & $13.3 \%$ & $3.4 \%$ & $8.9 \%$ & $2.0 \%$ & $4.5 \%$ & $1.4 \%$ & $6.5 \%$ & $1.3 \%$ \\
\hline tenure & 2004 & $64.2 \%$ & $10.9 \%$ & $4.8 \%$ & $3.7 \%$ & $2.1 \%$ & $4.7 \%$ & $0.4 \%$ & $8.5 \%$ & $0.8 \%$ \\
\hline & & & & & & & & & & \\
\hline & 1992 & $81.1 \%$ & $2.7 \%$ & $1.4 \%$ & $2.9 \%$ & $0.0 \%$ & $5.8 \%$ & $1.2 \%$ & $4.9 \%$ & $0.0 \%$ \\
\hline Five or more years & 1998 & $82.6 \%$ & $3.9 \%$ & $0.9 \%$ & $1.8 \%$ & $0.9 \%$ & $4.0 \%$ & $1.2 \%$ & $4.5 \%$ & $0.1 \%$ \\
\hline tenure & 2004 & $80.7 \%$ & $4.4 \%$ & $1.8 \%$ & $2.1 \%$ & $0.9 \%$ & $4.1 \%$ & $1.0 \%$ & $4.7 \%$ & $0.2 \%$ \\
\hline No pension & 1992 & $65.1 \%$ & $7.2 \%$ & $3.3 \%$ & $7.4 \%$ & $0.0 \%$ & $6.4 \%$ & $1.7 \%$ & $9.0 \%$ & $0.0 \%$ \\
\hline & 1998 & $62.5 \%$ & $10.3 \%$ & $2.5 \%$ & $7.4 \%$ & $1.9 \%$ & $5.3 \%$ & $1.3 \%$ & $7.5 \%$ & $1.2 \%$ \\
\hline & 2004 & $58.1 \%$ & $12.1 \%$ & $4.9 \%$ & $4.6 \%$ & $2.9 \%$ & $6.4 \%$ & $0.5 \%$ & $10.0 \%$ & $0.5 \%$ \\
\hline & & & & & & & & & & $0.0 \%$ \\
\hline DC pension only & $\begin{array}{l}1992 \\
1998\end{array}$ & $\begin{array}{l}83.6 \% \\
78.2 \%\end{array}$ & $\begin{array}{l}2.5 \% \\
6.9 \%\end{array}$ & $\begin{array}{l}1.7 \% \\
1.8 \%\end{array}$ & $\begin{array}{l}2.8 \% \\
4.5 \%\end{array}$ & $\begin{array}{l}0.0 \% \\
0.2 \%\end{array}$ & $\begin{array}{l}5.2 \% \\
2.6 \%\end{array}$ & $\begin{array}{l}0.1 \% \\
1.2 \%\end{array}$ & $\begin{array}{l}4.1 \% \\
4.3 \%\end{array}$ & $\begin{array}{l}0.0 \% \\
0.2 \%\end{array}$ \\
\hline & 2004 & $82.2 \%$ & $4.2 \%$ & $2.9 \%$ & $2.0 \%$ & $0.4 \%$ & $3.3 \%$ & $0.1 \%$ & $4.5 \%$ & $0.4 \%$ \\
\hline & & & & & & & & & & \\
\hline DB pension & 1992 & $82.3 \%$ & $1.9 \%$ & $1.5 \%$ & $2.4 \%$ & $0.0 \%$ & $6.0 \%$ & $1.4 \%$ & $4.4 \%$ & $0.0 \%$ \\
\hline & 1998 & $81.9 \%$ & $4.8 \%$ & $1.2 \%$ & $1.4 \%$ & $1.5 \%$ & $4.3 \%$ & $1.4 \%$ & $3.5 \%$ & $0.0 \%$ \\
\hline & 2004 & $83.4 \%$ & $4.3 \%$ & $1.1 \%$ & $1.4 \%$ & $0.7 \%$ & $3.3 \%$ & $1.7 \%$ & $3.8 \%$ & $0.3 \%$ \\
\hline
\end{tabular}


Table 3A: Relative Risk Ratios - Employment Transitions of Men Aged 50-59

\begin{tabular}{|c|c|c|c|c|c|c|c|c|c|c|c|c|c|}
\hline \multirow[t]{3}{*}{ Socio-Economic Variables } & & \multicolumn{6}{|c|}{ Transitions to a new job } & \multicolumn{6}{|c|}{ Transitions out of the labor force } \\
\hline & & \multicolumn{2}{|c|}{ Involuntary } & \multicolumn{2}{|c|}{ Pressured } & \multicolumn{2}{|c|}{ Voluntary } & \multicolumn{2}{|c|}{ Involuntary } & \multicolumn{2}{|c|}{ Pressured } & \multicolumn{2}{|c|}{ Voluntary } \\
\hline & & RRR & Robust SE & RRR & Robust SE & RRR & Robust SE & RRR & Robust SE & RRR & Robust SE & RRR & Robust SE \\
\hline Married & & 0.882 & 0.156 & 0.543 & 0.175 & 1.375 & 0.207 & 0.592 & 0.090 & 0.552 & 0.119 & 0.764 & 0.135 \\
\hline Homeowner & & 1.100 & 0.212 & 1.337 & 0.470 & 0.792 & 0.123 & 0.987 & 0.175 & 0.871 & 0.232 & 1.171 & 0.245 \\
\hline Black & & 0.788 & 0.184 & 1.518 & 0.600 & 0.814 & 0.138 & 1.093 & 0.198 & 0.594 & 0.200 & 1.196 & 0.246 \\
\hline Hispanic & & 0.757 & 0.188 & 0.389 & 0.190 & 0.569 & 0.154 & 0.957 & 0.251 & 0.350 & 0.165 & 0.967 & 0.291 \\
\hline \multirow[t]{2}{*}{ Education } & Less than high school & 1.390 & 0.288 & 0.705 & 0.332 & 0.472 & 0.102 & 1.135 & 0.215 & 0.976 & 0.320 & 0.563 & 0.128 \\
\hline & Some college & 0.916 & 0.163 & 0.868 & 0.315 & 1.250 & 0.167 & 0.913 & 0.136 & 1.176 & 0.262 & 0.990 & 0.156 \\
\hline Self-reported good health & & 0.882 & 0.117 & 0.977 & 0.296 & 1.025 & 0.112 & 0.552 & 0.074 & 1.066 & 0.200 & 0.761 & 0.099 \\
\hline Has health insurance & & 0.723 & 0.114 & 0.835 & 0.267 & 0.648 & 0.082 & 0.598 & 0.091 & 0.551 & 0.124 & 0.995 & 0.191 \\
\hline \multirow[t]{3}{*}{ Industry } & Agriculture and mining & 2.114 & 0.476 & 1.233 & 0.561 & 1.114 & 0.217 & 1.667 & 0.363 & 0.402 & 0.179 & 0.689 & 0.196 \\
\hline & $\begin{array}{l}\text { Manufacuring and } \\
\text { transportation } \\
\text { Professional services }\end{array}$ & 1.540 & 0.301 & 0.867 & 0.385 & 0.619 & 0.093 & 1.184 & 0.202 & 1.131 & 0.278 & 0.882 & 0.147 \\
\hline & and trade & 0.996 & 0.194 & 1.046 & 0.365 & 0.863 & 0.115 & 0.716 & 0.130 & 0.864 & 0.204 & 0.650 & 0.117 \\
\hline \multirow[t]{2}{*}{ Occupation } & White collar & 1.146 & 0.216 & 0.573 & 0.204 & 1.026 & 0.147 & 1.096 & 0.219 & 0.826 & 0.196 & 0.953 & 0.174 \\
\hline & Blue collar & 0.931 & 0.166 & 0.549 & 0.183 & 1.138 & 0.164 & 1.051 & 0.157 & 0.930 & 0.220 & 0.936 & 0.170 \\
\hline Union member & & 1.074 & 0.186 & 0.600 & 0.238 & 0.934 & 0.137 & 1.392 & 0.199 & 0.767 & 0.169 & 1.236 & 0.178 \\
\hline Hourly wage & & 0.993 & 0.008 & 1.000 & 0.002 & 0.999 & 0.001 & 0.997 & 0.004 & 1.000 & 0.000 & 1.000 & 0.000 \\
\hline Unemployment rate & & 0.989 & 0.025 & 1.109 & 0.036 & 0.936 & 0.027 & 1.008 & 0.026 & 0.927 & 0.042 & 1.062 & 0.029 \\
\hline \multirow[t]{3}{*}{ Self-reported pension type } & DB pension plan only & 0.442 & 0.088 & 0.430 & 0.201 & 0.704 & 0.114 & 0.496 & 0.093 & 0.851 & 0.230 & 1.097 & 0.194 \\
\hline & DC pension plan only & 0.618 & 0.106 & 0.509 & 0.176 & 0.514 & 0.072 & 0.469 & 0.084 & 0.581 & 0.153 & 0.459 & 0.100 \\
\hline & $\begin{array}{l}\text { DB and DC pension } \\
\text { plans } \\
\text { Between } 10 \text { and } 20\end{array}$ & 0.333 & 0.082 & 0.975 & 0.404 & 0.333 & 0.066 & 0.527 & 0.103 & 0.590 & 0.182 & 0.636 & 0.132 \\
\hline \multirow{2}{*}{ Years tenure in current job } & years & 0.299 & 0.060 & 0.344 & 0.143 & 0.317 & 0.055 & 0.536 & 0.097 & 0.396 & 0.120 & 0.445 & 0.100 \\
\hline & Over 20 years & 0.237 & 0.046 & 0.302 & 0.135 & 0.406 & 0.058 & 0.709 & 0.112 & 1.090 & 0.243 & 1.824 & 0.257 \\
\hline \multirow[t]{4}{*}{ Financial wealth } & 1st wealth quintile & 0.882 & 0.169 & 1.381 & 0.593 & 1.200 & 0.211 & 1.191 & 0.215 & 0.787 & 0.225 & 0.760 & 0.158 \\
\hline & 2nd wealth quintile & 0.866 & 0.177 & 1.793 & 0.765 & 1.172 & 0.220 & 0.938 & 0.190 & 0.803 & 0.234 & 0.922 & 0.198 \\
\hline & 4th wealth quintile & 0.928 & 0.184 & 1.476 & 0.650 & 1.268 & 0.214 & 0.988 & 0.188 & 0.751 & 0.207 & 0.846 & 0.166 \\
\hline & 5 th wealth quintile & 1.047 & 0.227 & 1.162 & 0.613 & 1.573 & 0.278 & 1.116 & 0.236 & 1.265 & 0.351 & 1.632 & 0.302 \\
\hline
\end{tabular}

Table 3B: Relative Risk Ratios - Employment Transitions of Women Aged 50-59

\begin{tabular}{|c|c|c|c|c|c|c|c|c|c|c|c|c|c|}
\hline \multirow[t]{3}{*}{ Socio-Economic Variables } & & \multicolumn{6}{|c|}{ Transitions to a new job } & \multicolumn{6}{|c|}{ Transitions out of the labor force } \\
\hline & & \multicolumn{2}{|c|}{ Involuntary } & \multicolumn{2}{|c|}{ Pressured } & \multicolumn{2}{|c|}{ Voluntary } & \multicolumn{2}{|c|}{ Involuntary } & \multicolumn{2}{|c|}{ Pressured } & \multicolumn{2}{|c|}{ Voluntary } \\
\hline & & RRR & Robust SE & RRR & Robust SE & RRR & Robust SE & RRR & Robust SE & RRR & Robust SE & RRR & Robust SE \\
\hline Married & & 0.748 & 0.113 & 0.645 & 0.156 & 0.740 & 0.090 & 0.862 & 0.111 & 0.657 & 0.113 & 1.056 & 0.134 \\
\hline Homeowner & & 0.976 & 0.174 & 0.605 & 0.204 & 0.679 & 0.094 & 0.809 & 0.118 & 1.160 & 0.302 & 0.997 & 0.177 \\
\hline Black & & 0.657 & 0.118 & 0.603 & 0.231 & 0.647 & 0.106 & 1.062 & 0.145 & 0.881 & 0.235 & 1.233 & 0.192 \\
\hline Hispanic & & 0.668 & 0.202 & 0.936 & 0.426 & 0.804 & 0.187 & 0.766 & 0.166 & 0.932 & 0.291 & 1.118 & 0.267 \\
\hline \multirow[t]{2}{*}{ Education } & Less than high school & 0.711 & 0.159 & 0.347 & 0.147 & 0.679 & 0.138 & 1.399 & 0.213 & 0.801 & 0.261 & 1.156 & 0.226 \\
\hline & Some college & 1.045 & 0.155 & 0.711 & 0.212 & 1.344 & 0.160 & 0.839 & 0.112 & 1.520 & 0.285 & 0.879 & 0.112 \\
\hline Self-reported good health & & 0.811 & 0.106 & 1.904 & 0.495 & 1.064 & 0.120 & 0.438 & 0.050 & 0.950 & 0.169 & 0.762 & 0.088 \\
\hline Has health insurance & & 1.011 & 0.137 & 0.598 & 0.165 & 0.639 & 0.077 & 0.720 & 0.090 & 0.826 & 0.146 & 0.558 & 0.070 \\
\hline \multirow[t]{3}{*}{ Industry } & $\begin{array}{l}\text { Agriculture and } \\
\text { mining }\end{array}$ & 2.086 & 0.915 & 0.275 & 0.288 & 1.487 & 0.558 & 1.649 & 0.685 & 2.473 & 1.302 & 0.733 & 0.405 \\
\hline & $\begin{array}{l}\text { Manufacuring and } \\
\text { transportation }\end{array}$ & 1.336 & 0.276 & 0.737 & 0.339 & 0.684 & 0.135 & 1.392 & 0.251 & 1.209 & 0.360 & 1.450 & 0.268 \\
\hline & Professional services an & 0.816 & 0.129 & 0.740 & 0.223 & 0.776 & 0.096 & 1.008 & 0.143 & 1.044 & 0.220 & 0.920 & 0.121 \\
\hline \multirow[t]{2}{*}{ Occupation } & White collar & 0.949 & 0.168 & 0.920 & 0.324 & 1.265 & 0.159 & 0.901 & 0.140 & 1.195 & 0.222 & 1.002 & 0.125 \\
\hline & Blue collar & 0.841 & 0.154 & 0.677 & 0.231 & 1.304 & 0.215 & 1.111 & 0.160 & 0.967 & 0.271 & 0.619 & 0.112 \\
\hline Union member & & 0.596 & 0.131 & 0.230 & 0.104 & 0.932 & 0.153 & 0.843 & 0.125 & 0.634 & 0.141 & 1.137 & 0.152 \\
\hline Hourly wage & & 0.987 & 0.008 & 0.966 & 0.023 & 1.000 & 0.001 & 0.987 & 0.008 & 1.000 & 0.001 & 1.000 & 0.001 \\
\hline Unemployment rate & & 0.993 & 0.031 & 1.120 & 0.043 & 0.926 & 0.028 & 1.049 & 0.022 & 0.932 & 0.044 & 1.042 & 0.025 \\
\hline \multirow[t]{3}{*}{ Self-reported pension type } & DB pension plan only & 0.302 & 0.069 & 0.278 & 0.113 & 0.438 & 0.079 & 0.653 & 0.102 & 0.533 & 0.121 & 0.880 & 0.129 \\
\hline & DC pension plan only & 0.584 & 0.094 & 0.596 & 0.192 & 0.490 & 0.072 & 0.630 & 0.091 & 0.606 & 0.131 & 0.517 & 0.082 \\
\hline & $\begin{array}{l}\text { DB and DC pension } \\
\text { plans } \\
\text { Between } 10 \text { and } 20\end{array}$ & 0.544 & 0.141 & 0.442 & 0.175 & 0.544 & 0.112 & 0.806 & 0.162 & 1.037 & 0.270 & 0.729 & 0.148 \\
\hline \multirow[t]{2}{*}{ Years tenure in current job } & years & 0.438 & 0.077 & 0.464 & 0.150 & 0.347 & 0.057 & 0.681 & 0.096 & 0.722 & 0.150 & 0.664 & 0.092 \\
\hline & Over 20 years & 0.350 & 0.084 & 0.595 & 0.253 & 0.642 & 0.104 & 0.927 & 0.149 & 0.721 & 0.157 & 1.261 & 0.173 \\
\hline \multirow[t]{4}{*}{ Financial wealth } & 1st wealth quintile & 1.096 & 0.219 & 0.983 & 0.365 & 0.942 & 0.146 & 1.134 & 0.184 & 1.131 & 0.306 & 0.485 & 0.090 \\
\hline & 2nd wealth quintile & 1.346 & 0.269 & 0.902 & 0.348 & 0.845 & 0.143 & 1.049 & 0.186 & 1.064 & 0.293 & 0.822 & 0.151 \\
\hline & 4th wealth quintile & 0.804 & 0.171 & 0.719 & 0.279 & 0.789 & 0.135 & 1.243 & 0.216 & 1.198 & 0.310 & 1.164 & 0.190 \\
\hline & 5 th wealth quintile & 0.850 & 0.195 & 0.757 & 0.333 & 0.882 & 0.150 & 1.263 & 0.241 & 1.420 & 0.363 & 1.823 & 0.293 \\
\hline
\end{tabular}




\begin{tabular}{|l|c|}
\hline Table 4: Likelihood Ratios- Tests of Pooling of Transition Categories \\
\hline Men & Difference in log likelihood \\
\hline Voluntary and pressured to new job & 123.7 \\
\hline Pressured and forced to new job & 118.1 \\
\hline Voluntary and pressured to not working & 14.6 \\
\hline Pressured and forced to not working & 66.1 \\
\hline Women & 85.0 \\
\hline Voluntary and pressured to new job & 85.3 \\
\hline Pressured and forced to new job & 65.9 \\
\hline Voluntary and pressured to not working & 113.1 \\
\hline Pressured and forced to not working & \\
\hline
\end{tabular}

Note: Model has 26 degrees of freedom, including the lost intercept 


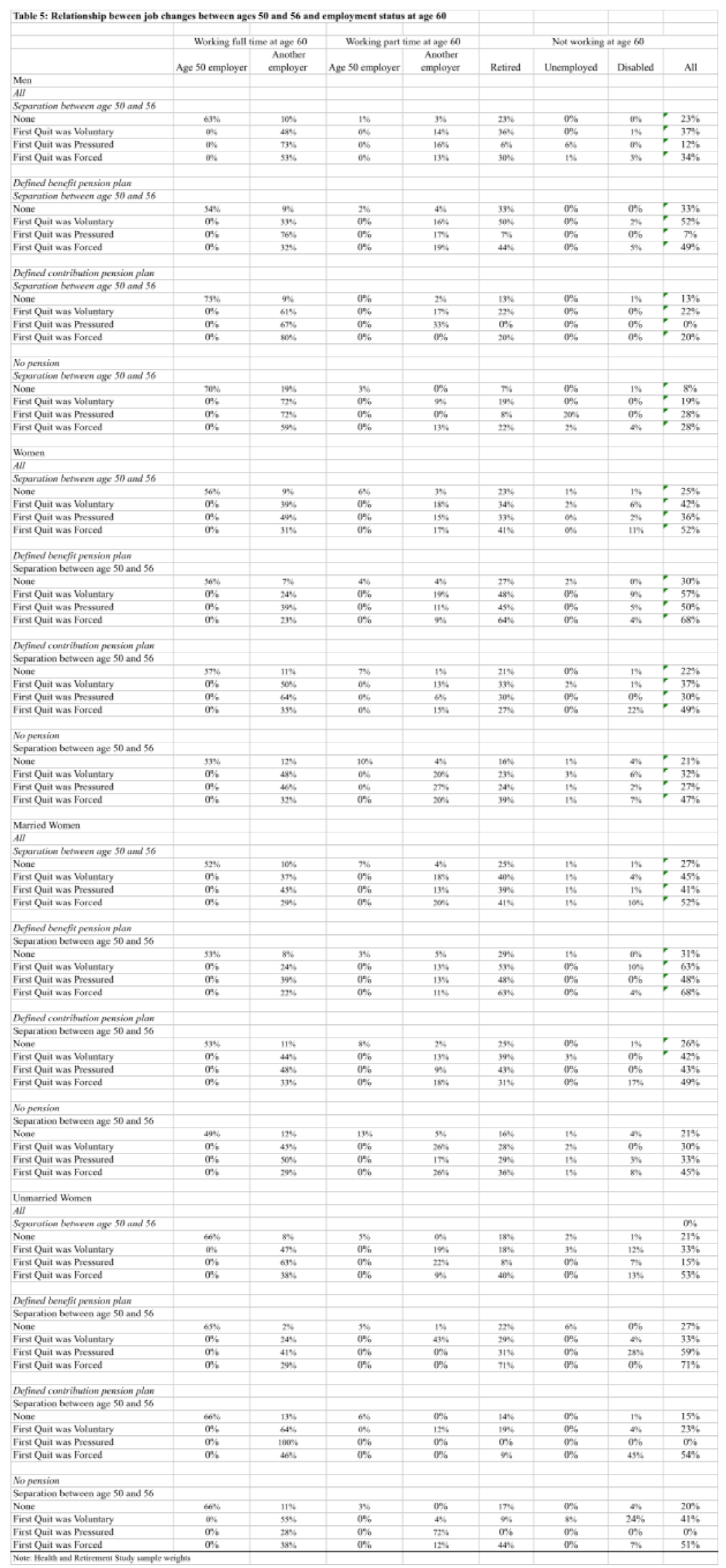




\begin{tabular}{|c|c|c|c|c|c|}
\hline \multicolumn{6}{|c|}{ Table 6: Relative Risk Ratios - Employment Transitions Aged 50} \\
\hline & & \multicolumn{4}{|c|}{ Employment Status at Age 60} \\
\hline & & \multicolumn{2}{|c|}{ Not Working } & \multicolumn{2}{|c|}{ Working Part Time } \\
\hline & & RRR & Robust SE & RRR & Robust SE \\
\hline First quit was voluntary & & 3.008 & 0.510 & 3.373 & 0.805 \\
\hline First quit was pressured & & 1.660 & 0.479 & 2.588 & 0.956 \\
\hline First quit was forced & & 4.036 & 0.796 & 4.249 & 1.182 \\
\hline \multicolumn{6}{|l|}{ Socio-Economic Variables } \\
\hline Married & & 1.517 & 0.273 & 1.670 & 0.440 \\
\hline Male & & 0.404 & 0.068 & 0.353 & 0.085 \\
\hline Homeowner & & 0.988 & 0.215 & 0.661 & 0.195 \\
\hline Black & & 1.011 & 0.263 & 0.740 & 0.309 \\
\hline Hispanic & & 0.931 & 0.298 & 1.447 & 0.642 \\
\hline \multirow[t]{2}{*}{ Education } & Less than high school & 2.574 & 0.648 & 1.498 & 0.604 \\
\hline & Some college & 1.077 & 0.221 & 2.217 & 0.614 \\
\hline \multicolumn{2}{|c|}{ Self-reported good health at age 50} & 1.004 & 0.153 & 1.361 & 0.304 \\
\hline \multicolumn{2}{|c|}{ Self-reported good health at age 60} & 2.336 & 0.432 & 1.113 & 0.328 \\
\hline Has health insurance & & 0.886 & 0.223 & 1.125 & 0.373 \\
\hline \multirow[t]{3}{*}{ Industry } & Agriculture and mining & 1.355 & 0.570 & 0.664 & 0.474 \\
\hline & Manfacturing and transportation & 1.438 & 0.295 & 0.604 & 0.215 \\
\hline & Professional services and government & 1.025 & 0.168 & 0.850 & 0.190 \\
\hline \multirow[t]{2}{*}{ Occupation } & White collar & 0.788 & 0.157 & 0.769 & 0.218 \\
\hline & Blue collar & 0.780 & 0.152 & 1.203 & 0.332 \\
\hline Union member & & 1.390 & 0.239 & 1.519 & 0.390 \\
\hline Hourly wage & & 1.015 & 0.009 & 0.992 & 0.012 \\
\hline \multirow[t]{3}{*}{ Self-reported pension type } & DB pension plan only & 1.710 & 0.375 & 0.721 & 0.225 \\
\hline & DC pension plan only & 1.024 & 0.213 & 0.645 & 0.181 \\
\hline & $\mathrm{DB}$ and DC pension plans & 2.202 & 0.508 & 1.221 & 0.383 \\
\hline \multirow[t]{2}{*}{ Years teure in current job } & Between 10 and 20 years & 1.123 & 0.205 & 0.801 & 0.220 \\
\hline & Over 20 years & 2.160 & 0.399 & 1.623 & 0.439 \\
\hline \multirow[t]{4}{*}{ Financial wealth } & 1st wealth quintile & 0.695 & 0.148 & 0.757 & 0.247 \\
\hline & 2nd wealth quintile & 0.819 & 0.184 & 1.081 & 0.357 \\
\hline & 4th wealth quintile & 0.774 & 0.159 & 1.042 & 0.309 \\
\hline & 5th wealth quintile & 0.923 & 0.199 & 1.304 & 0.404 \\
\hline
\end{tabular}

Table 7: Impact of age 50-56 quits on probability of working at age 60

\begin{tabular}{|l|r|r|r|}
\hline \multirow{5}{*}{ Table 7: Impact of age 50-56 quits on probability of working at age 60 } \\
\hline & \multicolumn{3}{|c|}{ Employment status } \\
\hline Quit type & Not working for pay & Part time & Full time \\
\hline None & $23.9 \%$ & $6.7 \%$ & $69.4 \%$ \\
\hline Voluntary & $43.9 \%$ & $13.8 \%$ & $42.3 \%$ \\
\hline Pressured & $31.4 \%$ & $13.7 \%$ & $54.9 \%$ \\
\hline Forced & $49.6 \%$ & $14.7 \%$ & $35.7 \%$ \\
\hline Notes: Authors' calculations. Holding all other chacateristics constant at the mean for the entire sample \\
\hline
\end{tabular}


Table 8: Long-term labor market outcomes by age 50-56 quit type

Percent working at age 60

None $\quad$ Volunt type

Number of months non-employment between first separation and first

$75 \%$

$60 \%$

Pressured

Forced

subsequent job (re-hires only)

Hourly wage earend in first subsequent job

Total nummber of months worked from age 50 to 60

Number of full time equivalent months worked from age 50 to 60

Total number of jobs held from age 50 to 60

Number of periods of self-employment from age 50 to 60

Number of times laid off between age 50 and 60

Note: Hrs sample weights

Figure 1A: Cumulative Distribution of Male Job Tenure Ages 50-59, 1992 and 2004

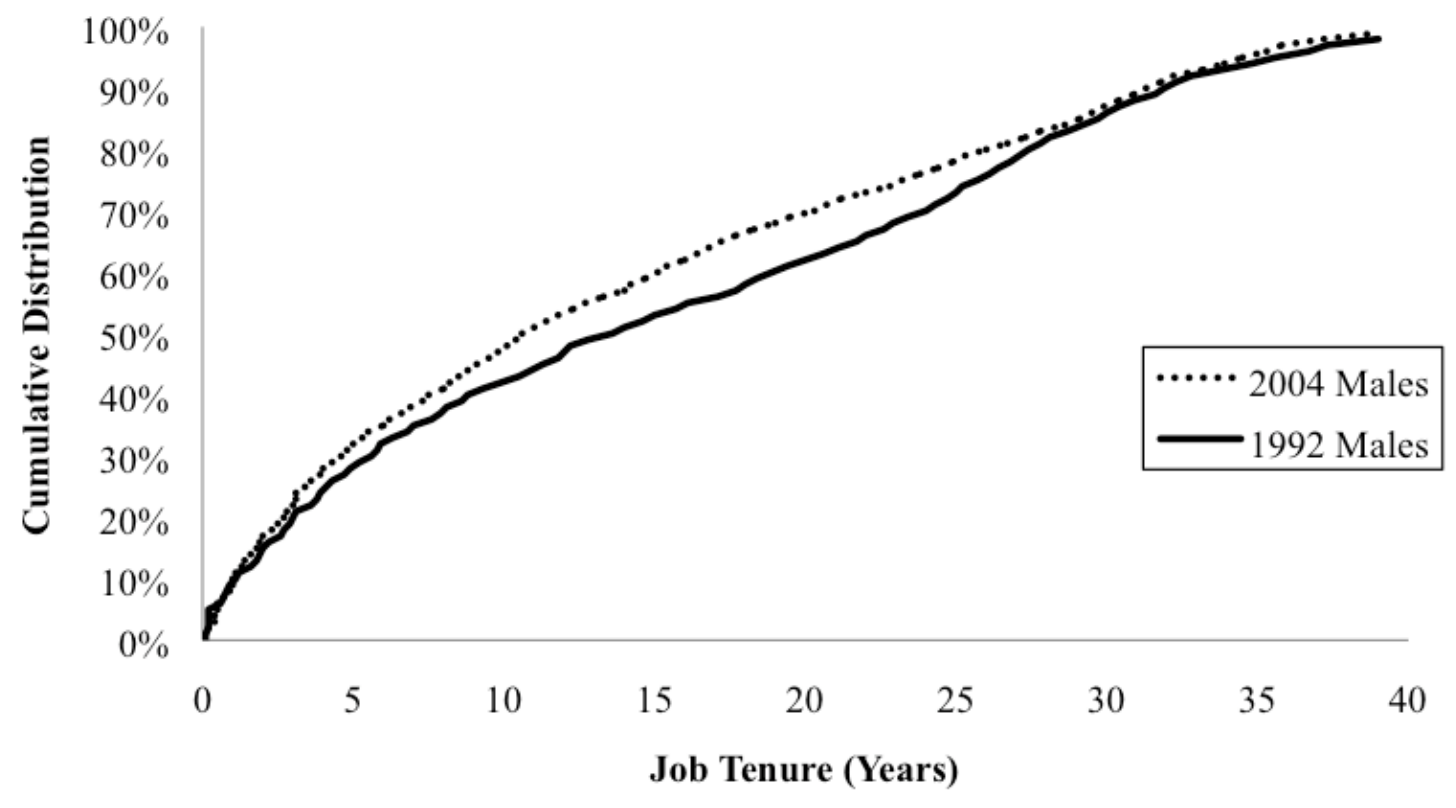


Figure 1B: Cumulative Distribution of Female Job Tenure Ages 50-59, 1992 and 2004

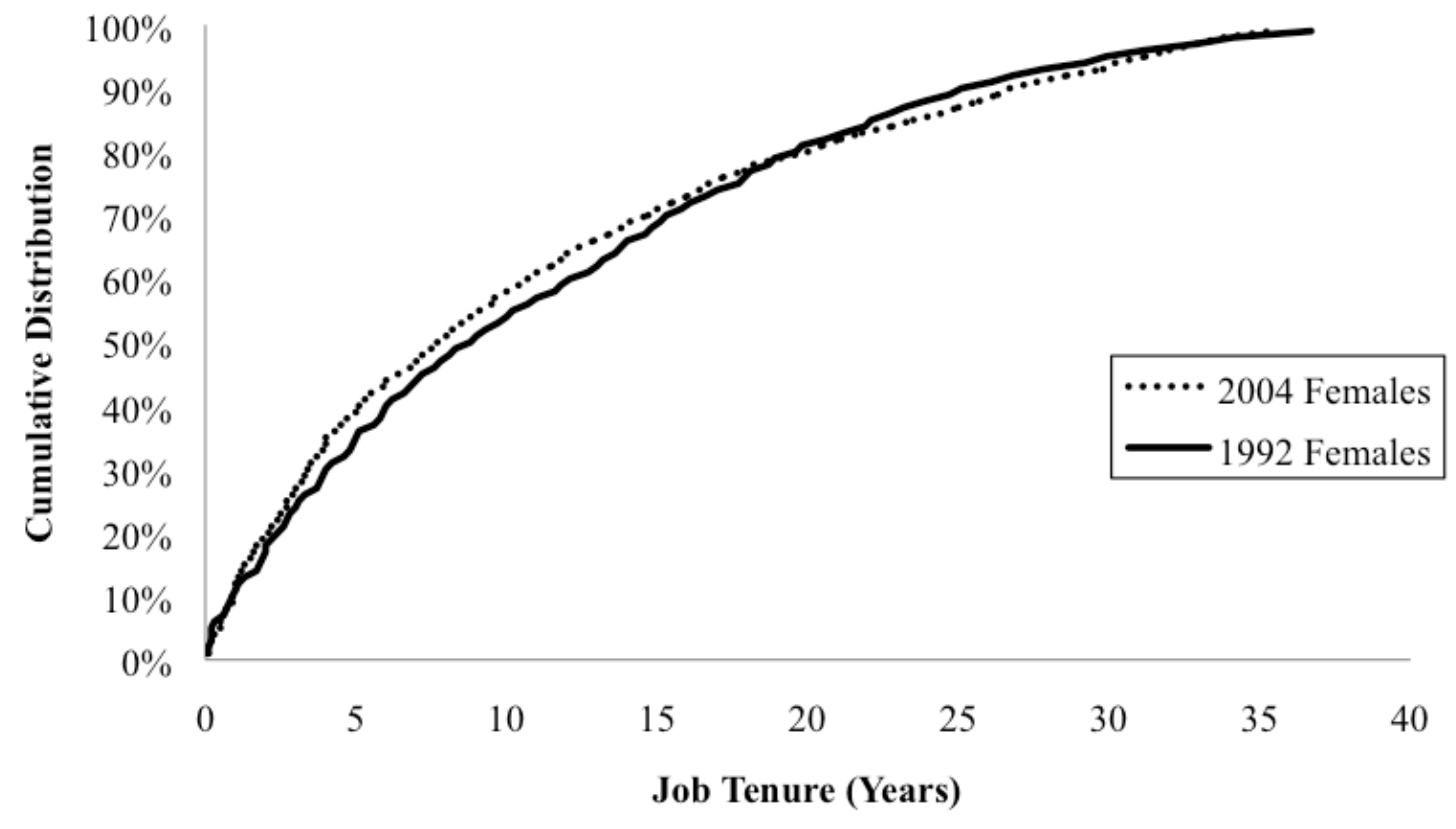




\section{RECENT WORKING PAPERS FROM THE}

\section{CENTER FOR RETIREMENT RESEARCH AT BOSTON COLLEGE}

Accounting for Disability Insurance in the Dynamic Relationship Between Disability Onset and Earnings

Perry Singleton, November 2010

The Treatment of Married Women by the Social Security Retirement Program

Andrew G. Biggs, Gayle L. Reznik, and Nada O. Eissa, November 2010

What is the Impact of Foreclosures on Retirement Security?

Irena Dushi, Leora Friedberg, and Anthony Webb, November 2010

Children and Household Utility: Evidence from Kids Flying the Coop

Norma B. Coe and Anthony Webb, November 2010

Overview of the CRR 2009 Retirement Survey

Alicia H. Munnell, Norma B. Coe, Kelly Haverstick, and Steven A. Sass, October 2010

State Wage-Payment Laws, the Pension Protection Act of 2006, and 401(k) Saving Behavior

Gary V. Englehardt, October 2010

Asset Cycles and the Retirement Decisions of Older Workers

Jan Ondrich, October 2010

Price Deflators, the Trust Fund Forecast, and Social Security Solvency

Barry Bosworth, October 2010

The Impact of a DROP Program on the Age of Retirement and Employer Pension Costs Samson Alva, Norma B. Coe, and Anthony Webb, September 2010

Housing Consumption in Late Life: The Role of Income, Health Shocks, and Marital Shocks

Douglas A. Wolf and Janet M. Wilmoth, September 2010

Adjusting Social Security for Increasing Life Expectancy: Effects on Progressivity

Courtney Monk, John A. Turner, and Natalia A. Zhivan, August 2010

Work and Retirement Patterns for the G.I. Generation, Silent Generation, and Early Boomers: Thirty Years of Change

Richard W. Johnson, Barbara A. Butrica, and Corina Mommaerts, July 2010

Spousal Health Shocks and the Timing of the Retirement Decision in the Face of ForwardLooking Financial Incentives

Courtney Harold Van Houtven and Norma B. Coe, June 2010

All working papers are available on the Center for Retirement Research website (http://crr.bc.edu) and can be requested by e-mail (crr@bc.edu) or phone (617-552-1762). 